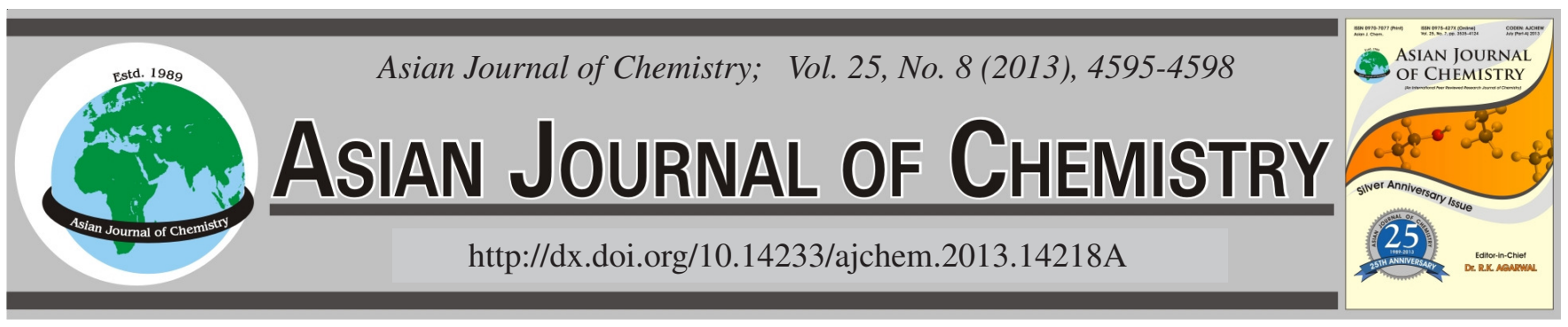

\title{
Antileukemic Properties of Spermacoce Species
}

\author{
M.A. Sukari ${ }^{1, *}$, R. Utami ${ }^{1}$, B.K. $\mathrm{NeOH}^{2}$, G.C.L. EE ${ }^{1}$, S. JusOH ${ }^{3}$, S.M.M. Nor ${ }^{1}$ and M. Rahmani ${ }^{1}$
}

\begin{abstract}
${ }^{1}$ Department of Chemistry, Faculty of Science, Universiti Putra Malaysia, 43400 Serdang, Selangor, Malaysia
${ }^{2}$ Sime Darby Technology Centre Sdn Bhd, Block A and B, UPM-MTDC Technology Centre III, Universiti Putra Malaysia, 43400 Selangor, Malaysia

${ }^{3}$ Department of Animal Science, Faculty of Agriculture, Universiti Putra Malaysia, 43400 Serdang, Selangor, Malaysia
\end{abstract}

*Corresponding author: E-mail: aspollah@science.upm.edu.my

\begin{abstract}
Antileukemic activity of th extracts and isolated compound from Spermacoce articularis, Spermacoce exilis and Spermacoce latifolia were carried out. All extracts of Spermacoce articularis as well as dichloromethane and ethyl acetate extracts of Spermacoce exilis showed strong activity against HL-60 cancer cell with $\mathrm{IC}_{50}$ value ranging from 0.4 to $7.2 \mu \mathrm{g} / \mathrm{mL}$, whereas hexane extract of Spermacoce latifolia gave moderate activity with $\mathrm{IC}_{50}$ value of $13 \pm 0.19 \mu \mathrm{g} / \mathrm{mL}$. Ursolic acid as the major isolated constituent of these plants was found to have strong activity with $\mathrm{IC}_{50}$ of $1.3 \pm 0.03 \mu \mathrm{g} / \mathrm{mL}$ against the same cancer cell.
\end{abstract}

Key Words: Spermacoce articularis, Spermacoce exilis, Spermacoce latifolia, Ursolic acid, Antileukemic.

\section{INTRODUCTION}

Spermacoce is a relatively large genus of herbs or halfshrubby plants. This genus consists of about 100 species distributed throughout the tropics. Several of them are united with Borreria, so that the Malayan species have synonyms under that same name ${ }^{1}$. Several studies revealed that some species of this genus showed antimicrobial activities against Staphylococcus aureus, Pseudomonas aeruginosa and Vibrio cholera and possessed high cytotoxicity ${ }^{2,3}$.

Spermacoce articularis (shaggy button weed) is a diffused herb found in tropical Asia and Peninsula Malaysia. It is commonly seen growing in sandy wastelands often in the coastal areas. A poultice of this plant is used to heal leg ulcers, wounds, headaches, toothaches. Spermacoce exilis is also found throughout Peninsular Malaysia. It commonly grows in wastelands and garden paths. It is used to treat headache, fever and ulcers. Spermacoce latifolia is a well known weed grass that being called "Ji Chao" (chicken grass) in Chinese. The Chinese also use Spermacoce latifolia to cure disease called "Zhu Mao Dan" that can bring vital effect.

A study by Saha et al. ${ }^{4}$ reported the extract from Spermacoce articularis showed strong DPPH free radical scavenging activity comparable with quercetin, BHT and vitamin C, whereas Spermacoce exilis showed only moderate activity. In Griess assay, Spermacoce articularis showed strong inhibitory activity on nitric oxide (NO) production in LPS and IFN- $\gamma$ induced RAW264.7 cells. Extracts from Spermacoce exilis also inhibited nitric oxide production but this was due to the cytotoxic effect upon cells during culture. Futher study by Vadivelan et al. ${ }^{5}$ showed that extracts of Spermacoce articularis have significant anti inflammatory effect on inhibiton on carragenan induced rat paw edema.

Previous phytochemical studies on Spermacoce articularis originated from India indicated the presence of flavonoids, triterpenoids and ursolic acid ${ }^{6,7}$. Our preliminary study revealed that ursolic acid and stigmasterol were isolated from Spermacoce articularis and Spermacoce exilis. Besides, benzo[g]isoquinoline-5,10-dione, hexadecanoic acid, sitosterol and pentatriacontane were also obtained from Spermacoce exilis ${ }^{8}$. Further isolation work on Spermacoce latifolia afforded ursolic acid, pentatriacontane, $\beta$-sitosterol as well as stigmasterol. Thus, here we report antileukemic activity study of extracts and isolated compound of Spermacoce articularis, Spermacoce exilis and Spermacoce latifolia.

\section{EXPERIMENTAL}

Cell culture and MTT assay: Leukemic cancer cell HL60 was obtained from American Type Culture Collection (ATCC), Maryland, USA. RPMI 1640 (PAA, Germany) was used as media for culturing cells. Disposable items $(75 \mathrm{~mL}$ tissue culture flask, 96 wells plates, tips) were purchased from NUNCTM, Denmark. Feotal Bouvine Serum and Penicilin Streptomycin were obtained from FlowLab, Australia. MTT (Mictrotetrazolium) powder was purchased from Amresco and 
the dimethylsulfoxide was purchased from Sigma Aldrich, Germany.

Isolation and characterization of constituents: Melting points (uncorrected) were determined using Kohfler melting points apparatus. The IR spectra were recorded using $\mathrm{KBr}$ disc on Perkin Elmer FTIR spectrophotometer $1650 .{ }^{1} \mathrm{H}$ and ${ }^{13} \mathrm{C}$ NMR spectra were obtained on JEOL spectrometer at 500 and $125 \mathrm{MHz}$, respectively with tetramethylsilane as internal standard. Mass spectra were recorded on an AE1-MS12 spectrometer. Separation by column chromatography was carried out using silica gel (Merck 7749 and 9385) and while silica gel $60 \mathrm{PF}_{254}$ was used for TLC analysis.

Both Spermacoce articularis and Spermacoce exilis were collected from Sungkai Reverse Forest in Perak, while Spermacoce latifolia was harvested from garden of faculty of Agriculture, Universiti Putra Malaysia. All the plants were identified by Mr. Shamsul Khamis, Institute of Bioscience (IBS), Universiti Putra Malaysia and voucher specimens were deposited at the IBS Herbarium.

Extraction and isolation: Isolation work on Spermacoce articularis $(600 \mathrm{~g})$ yielded two compounds, stigmasterol (0.018 $\mathrm{g}$ ) and ursolic acid (1) (1.452 g). While $600 \mathrm{~g}$ of Spermacoce exilis gave ursolic acid (1) (0.30 g), benzo[g]isoquinoline-5,10dione (2) (0.008 g), hexadecanoic acid (3) (0.015 g) and stigmasterol (4) $(0.023 \mathrm{~g})$. The detail isolation works are as described in our previous report ${ }^{8}$.

The finely ground air-dried Spermacoce latifolia (1.208 $\mathrm{kg}$ ) was extracted three times with hexane, dichloromethane and ethyl acetate sequentially for $72 \mathrm{~h}$ for each solvent at room temperature. The solvents were removed under reduced pressure to give hexane, dichloromethane and ethyl acetate extracts. Each extract was purified by silica gel column chromatography using mixture of hexane and ethyl acetate as solvents. The hexane extract gave stigmasterol (4) and pentatriacontane, while dicloromethane extract gave ursolic acid (1) and sitosterol (5).

Ursolic acid (1): Colourless crystals; m.p. $270-272{ }^{\circ} \mathrm{C}$ (lit m.p. 276-279 ${ }^{\circ} \mathrm{C}^{9}$ ). IR ( $\left.\mathrm{KBr}, v_{\max }, \mathrm{cm}^{-1}\right)$ : 3446, 2392, 1698, 1456, 1382, 1244, 1036, 998, 664. EI-MS m/z (\% intensity): $456\left(\mathrm{M}^{+}, 3\right), 438$ (1), 423 (1), 248 (100), 219 (18), 203 (42). The ${ }^{1} \mathrm{H}$ and ${ }^{13} \mathrm{C}$ NMR data were described in previous report ${ }^{8}$.

Benzo[g]isoquinoline-5,10-dione (2): Green needleshaped crystals; m.p. $178-180{ }^{\circ} \mathrm{C}$ (lit m.p. $\left.178-179^{\circ} \mathrm{C}^{10}\right)$. IR ( $\left.\mathrm{KBr}, \mathrm{v}_{\max }, \mathrm{cm}^{-1}\right): 3582,2920,2850,1678,1578,1302,1142$, 1022, 946, 922, 858, 792, 702. EI-MS m/z (\% intensity): 210 $\left(\mathrm{M}^{+}, 100\right), 181$ (57), 153 (99), 126 (71), 99 (12). The ${ }^{1} \mathrm{H}$ and ${ }^{13} \mathrm{C}$ NMR data were described in previous report ${ }^{8}$.

Hexadecanoic acid (3): White crystal; m.p. $38-40{ }^{\circ} \mathrm{C}$ (lit m.p. $\left.38-40^{\circ} \mathrm{C}^{11}\right)$. IR $\left(\mathrm{KBr}, v_{\max }, \mathrm{cm}^{-1}\right): 3438,2920,2850,1738$, 1468, 1174, 724. EI-MS m/z (\% intensity): $256\left(\mathrm{M}^{+}, 44\right), 242$ (2), 227 (88), 185 (22), 129 (67), 85 (42), 55 (100). The ${ }^{1} \mathrm{H}$ and ${ }^{13} \mathrm{C}$ NMR data were described in previous report ${ }^{8}$.

Stigmasterol (4): Colourless needles crystal, m.p. 158$160{ }^{\circ} \mathrm{C}$ (lit m.p. $176{ }^{\circ} \mathrm{C}^{12}$ ), IR $v_{\max }: 3434,2985,2936,1636$. MS m/z (\% intensity): $412\left(\mathrm{M}^{+}, 70\right), 133$ (30), 105 (35), 83 (60), 55 (100). ${ }^{1} \mathrm{H}$ and ${ }^{13} \mathrm{C}$ NMR data were in a good agreement with the previous data ${ }^{12}$.

$\boldsymbol{\beta}$-Sitosterol (5): White needles crystal, m.p. $137-138^{\circ} \mathrm{C}$ $\left(137-138^{\circ} \mathrm{C}^{13}\right)$, IR $\nu_{\max }: 3341,2934,2865,1657,1460 . \mathrm{MS} \mathrm{m} / \mathrm{z}$
(\% intensity): 414 ( $\left.\mathrm{M}^{+}, 77\right), 396$ (49), 381 (34), 329 (67), 255 (70), 213 (69), 145 (100), 105 (91), 81 (90). ${ }^{1} \mathrm{H}$ and ${ }^{13} \mathrm{C}$ NMR data were in a good agreement with the previous data ${ }^{13}$.

Cytotoxic assay: The extracts and ursolic acid as isolated compound from weeds of Spermacoce articularis, Spermacoce exilis and Spermacoce latifolia were screened for cytotoxic activity against HL-60 (human promyelocytic leukemia) cancer cell. The test was carried out in accordance to the method described by Mosmann ${ }^{14}$. The medium was used to dilute the cells to a concentration of $5 \times 10^{3}$ cells $/ \mathrm{mL}$. From this cell suspension, $100 \mathrm{~mL}$ of various concentrations of the extracts was pippeted into a 96-well microtiter plate and incubated in $37^{\circ} \mathrm{C}, 5 \% \mathrm{CO}_{2}$ for $72 \mathrm{~h}$. The various concentration used were $30,15,7.5,3.75,1.86,0.94$ and $0.47 \mu \mathrm{g} / \mathrm{mL}$. The assays of each concentration of extracts were performed in triplicates and the control well of untreated population were also included. After 3 days, the fraction of surviving cells were determined relative to the untreated cell population by the colourimeter MTT (3-[4,5-dimethylthiozol 1-2yl]-2,5diphenyltetrazolium bromide) method where the viability of cells was measured by $20 \mu \mathrm{L}$ of blue formazan crystals of MTT solution ( $5 \mathrm{mg} / \mathrm{mL}$ in PBS, freshly prepared before assay) was added to each well at $37^{\circ} \mathrm{C}$ for $4 \mathrm{~h}$ incubation. One hundred microliter of the medium was removed from each well. The plate was left at room temperature for $30 \mathrm{~min}$ before reading the absorbance. The absorbance was read with the ELISA reader test wavelength of $570 \mathrm{~nm}$ and reference wavelength of $630 \mathrm{~nm}$. The $\mathrm{IC}_{50}$ value was defined as the concentration of the test compound resulting in a $50 \%$ reduction of absorbance.

\section{RESULTS AND DISCUSSION}

In this investigation, all crude extracts of three Spermacoce species, Spermacoce articularis, Spermacoce exilis and Spermacoce latifolia and its isolated compound were evaluated for their antileukemic activity using MTT assay towards HL60 cancer cell line. All extracts of studied plants were obtained from cold maceration process using three solvents with different polarity, including hexane, dichloromethane and ethyl acetate. Isolation works on the extracts yielded ursolic acid (1) as major constituent of Spermacoce articularis, Spermacoce exilis and Spermacoce latifolia. Besides ursolic acid (1), stigmasterol (4) was also isolated from all of these studied plants. In addition, benzo[g]isoquinoline-5,10-dione (2) and hexadecanoic acid (3) were isolated from extract of Spermacoce exilis. While, pentatriacontane has been obtained from extract of Spermacoce latifolia along with $\beta$-sitosterol (5). All the compounds were elucidated using several spectroscopic techniques including IR, MS, ${ }^{1} \mathrm{H},{ }^{13} \mathrm{C}$ NMR, ${ }^{2} \mathrm{D}$ NMR and comparison with data in literatures. The isolation and characterization of ursolic acid (1) and other isolated compounds have been described in details in our previous report ${ }^{8}$.

As for the cytotoxic activity, all extracts and ursolic acid (1) were screened against HL-60 leukemic cancer cell line. Most of the extracts of Spermacoce species exhibited high cytotoxicity against HL-60 cell. The test was carried out in accordance to the method as described by Mosmann ${ }^{14}$. Table1 shows antileukemic activity of extracts and ursolic acid towards HL-60 cancer cell. Ethyl acetate extract of Spermacoce 
articularis exhibited the highest cytotoxic activity with $\mathrm{IC}_{50}$ $0.4 \pm 0.08 \mu \mathrm{g} / \mathrm{mL}$, followed by hexane and dichloromethane extracts with $0.9 \pm 0.02$ and $7.2 \pm 0.12 \mu \mathrm{g} / \mathrm{mL}$, respectively. Besides hexane extract, both dichloromethane and ethyl acetate extract from Spermacoce exilis showed strong activity against the same cell with $\mathrm{IC}_{50} 0.65 \pm 0.05$ and $3.75 \pm 0.07 \mu \mathrm{g} /$ $\mathrm{mL}$, respectively. However, as for Spermacoce latifolia, only hexane extract demonstrated moderate activity against the same cell with $\mathrm{IC}_{50}$ value of $13.0 \pm 0.19 \mu \mathrm{g} / \mathrm{mL}$. For the isolated compound, ursolic acid (1) showed strong cytotoxic activity against HL-60 cancer cell with $\mathrm{IC}_{50}$ value of $1.3 \pm 0.03 \mu \mathrm{g}$ / $\mathrm{mL}$.

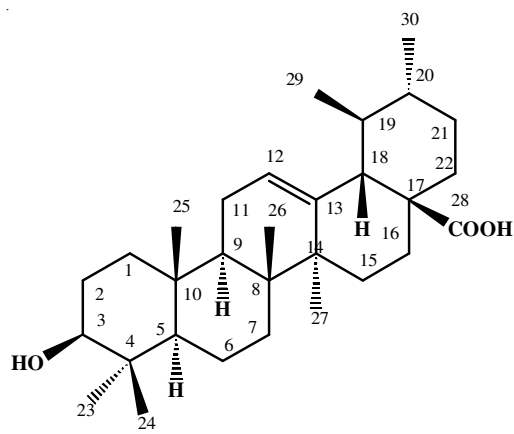

(1)

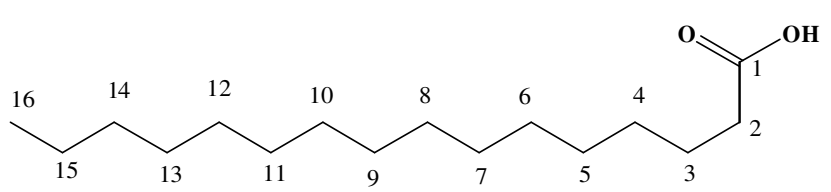

(3)

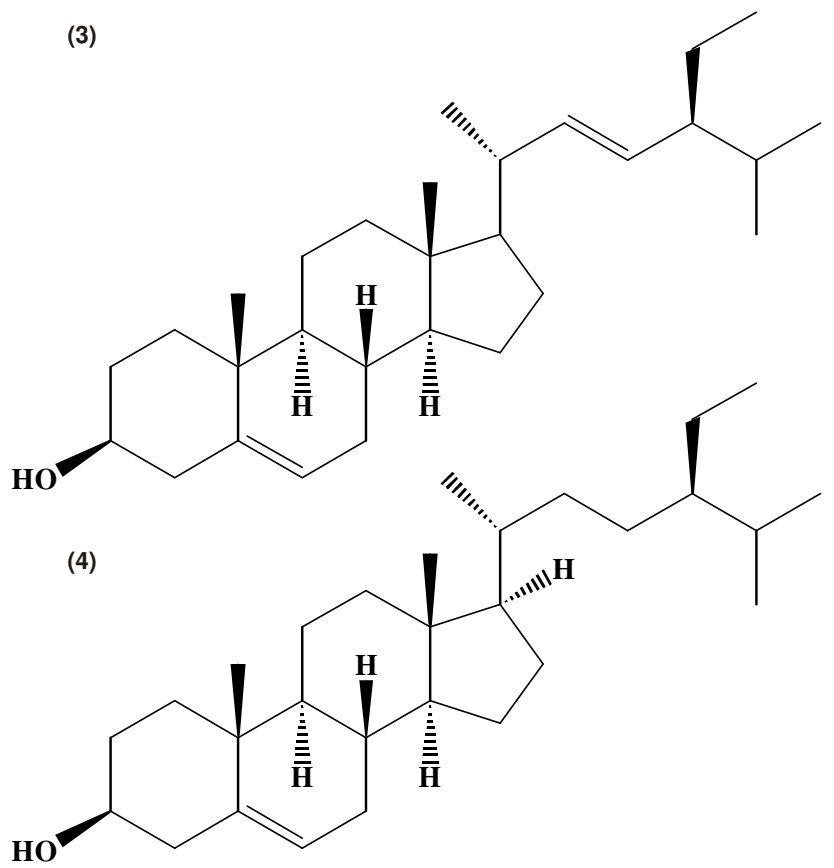

(5)

The strong cytotoxic activity of some extracts of Spermacoce species, which are hexane extract of Spermacoce articularis and both dichloromethane extracts of Spermacoce exilis and Spermacoce latifolia might be due to the presence of ursolic acid. As previous report revealed that ursolic acid is a pentacyclic triterpene which showed anti tumor effects and chemopreventive properties in normal cells. Ursolic acid is capable of inducing apoptosis in tumor cells on one side and to prevent malignant transformation of normal cells on the other side. It also interferes with numerous enzymes, including the ones serving directly to DNA synthesis ${ }^{15}$. This compound has been reported as active constituent of some plants species from family Labiatae, Myrtaceae, Rubiaceae, Solanaceae which afforded beneficial activities including anti-inflammatory, hepatoprotection and antimicrobial as well as antitumor activities. Ursolic acid was also revealed as active constituent that contributes to antileukemic activity of Calluna vulgaris (Ericaceae) and Psychotria serpens L. (Rubiaceae) ${ }^{16}$. Cytotoxic activity of Spermacoce species against HL-60 leukemic cancer cell has never been reported previously.

\begin{tabular}{lll}
\multicolumn{3}{c}{ TABLE-1 } \\
$\begin{array}{l}\text { ANTILEUKEMIC ACTIVITY RESULTS OF Spermacoce articularis, } \\
\text { Spermacoce exilis AND Spermacoce latifolia AGAINST } \\
\text { HL-60 CANCER CELL LINE }\end{array}$ \\
\hline Plants & Extracts & $\mathrm{IC}_{50}(\mu \mathrm{g} / \mathrm{mL})$ \\
\hline S. articularis & Hexane & $0.9 \pm 0.02$ \\
& Dichloromethane & $7.2 \pm 0.12$ \\
S. exilis & Ethyl Acetate & $0.4 \pm 0.08$ \\
& Hexane & $>30$ \\
& Dichloromethane & $0.65 \pm 0.05$ \\
S. latifolia & Ethyl Acetate & $3.75 \pm 0.07$ \\
& Hexane & $13 \pm 0.19$ \\
& Dichloromethane & $>30$ \\
Ursolic acid & Ethyl Acetate & $>30$ \\
\hline
\end{tabular}

Hexane extract of Spermacoce articularis and dichloromethane extract of Spermacoce exilis show synergistic effect since the $\mathrm{IC}_{50}$ value of ursolic acid was higher than $\mathrm{IC}_{50}$ value of its extracts. Whereas, the less active cytotoxic activity of dichloromethane extract of Spermacoce latifolia with $\mathrm{IC}_{50}$ value $>30 \mu \mathrm{g} / \mathrm{mL}$ resulted from antagonistic effect of ursolic acid and the other compounds in this extract.

\section{Conclusion}

Antileukemic activity of extracts of three Spermacoce species and its isolated compound, ursolic acid have been carried out using MTT Assay towards HL-60 cancer cell. Ursolic acid as major constituent of these plants demonstrated strong antileukemic activity with $\mathrm{IC}_{50}$ value of $1.3 \pm 0.03 \mu \mathrm{g} /$ $\mathrm{mL}$. Some of extracts also showed potential activity and it might be due to the presence of ursolic acid in these extracts.

\section{ACKNOWLEDGEMENTS}

The authors thank FRGS and GRF programme of the Malaysian Government for financial assistances.

\section{REFERENCES}

1. I.H. Burkill, Dictionary of Economic Products from Malay Peninsula. The Ministry of Agriculture \& Cooperatives, Kuala Lumpur, vol. 1-2, 1297 (1966).

2. A.M. Balde, A. Gergely, L.A. Pieters, M. Claeys, D.A.V. Berghe and A.J. Vlietinck, Planta Med., 55, 652 (1989).

3. P.A.S.P. Neto, M.V. Silva, N.V.C. Campos, Z. Porfirio and L.C. Caetano, Fitoterapia, 73, 529 (2002).

4. K. Saha, N.H. Lajis, D.A. Israf, A.S. Hamzah, S. Khozirah, S. Khamis and A. Syahida, J. Ethnopharmacol., 92, 263 (2004).

5. S. Vadivelan, B.N. Sinha, S.B. Kalyan, A.J.M. Christina and N.P. Rakesh, Pharmacologyonline, 3, 478 (2007). 
6. K.S. Mukherjee, T.K. Manna, S. Laha and C.K. Chakravorty, J. Indian Chem. Soc., 70, 609 (1993).

7. K.K. Purushothaman and K. Kalyani, J. Res. Indian Med. Yoga Homeop., 14, 131 (1979)

8. N.B. Keat, R.U. Umar, N.H. Lajis, Y.C. Tai, Y.L. Tu, M. Rahmani and M.A. Sukari, Malaysian J. Anal. Sci., 14, 6 (2010).

9. A.V. Tkachev, A.Y. Denisov, Y.V. Gatilov, I.Y. Bagryanskaya, S.A. Shevtsov and T.V. Rybova, Tetrahedron, 50, 11459 (1994).
10. A.L. Okunade, A.M. Clark, C.D. Hufford and B.O. Oguntimein, Planta Med., 65, 447 (1999).

11. A.N. Patra and S.K. Chauduri, J. Indian Chem. Soc., 65, 367 (1988).

12. M.R. Habib, F. Nikkon, M. Rahman, M.E. Haque and M.R. Karim, Pak. J. Biol. Sci., 10, 4174 (2007).

13. F. Ahmad, M. Ali and P. Alam, Nat. Prod. Res., 24, 926 (2010).

14. T. Mosmann, J. Immunol. Meth., 65, 55 (1983).

15. L. Novotny, A. Vachalkova and D. Biggs, Neoplasma, 48, 241 (2001).

16. J. Liu, J. Ethnopharmacol., 49, 57 (1995). 